\title{
Stimulation of gonad maturation in mullet fish Mugil dussumieri using MT, E2, hCG, and Ovaprim hormone
}

\section{Stimulasi pematangan gonad ikan belanak Mugil dussumieri menggunakan hormon MT, E2, hCG, dan Ovaprim}

\author{
Tatak Dwi Cahyono $^{1 *}$, Muhammad Zairin Jr${ }^{1}$, Odang Carman ${ }^{1}$ \\ 'Department of Aquaculture, Faculty of Fisheries and Marine Sciences, IPB University \\ Dramaga, Bogor, West Java 16680, Indonesia \\ *Corresponding author : tatakdc@gmail.com, zairinmz@live.com
}

(Received December 12, 2018; Accepted December 24, 2018)

\begin{abstract}
The present study is a preliminary research for producing mullet fry. The research aimed to evaluate stimulation of gonad maturation in mullet using hormones. The method used for research was completely randomized design consist of three treatments and each individual replication was repeated three times. Two experiments were conducted separately. First experiment used 9-14.7 cm body length of fish treated with different hormone injections i.e. 4 $\mathrm{mg} / \mathrm{kg} 17 \alpha$-methyltestosterone (MT), $0.07 \mathrm{mg} / \mathrm{kg}$ estradiol-17 $\beta$ (E2), and $0.5 \mathrm{ml} / \mathrm{kg} 0.9 \%$ physiological solution as control. Second experiment used 10-31 cm body length fish treated with $750 \mathrm{IU} / \mathrm{kg}$ chorionic gonadotropin (hCG), $0.5 \mathrm{ml} / \mathrm{kg}$ Ovaprim, and $0.9 \%$ physiological solution as control. Gonadosomatic index (GSI) value of the first experiment on day 60 showed that GSI of E2 treatment was higher than both MT treatment and control. On the contrary, the second experiment on day 60 showed that GSI of hCG treatment was higher than both Ovaprim treatment and control. Egg diameter frequency distribution for control in the first experiment on day 30 ranged from 9-144 $\mu \mathrm{m}$. Egg diameter for E2 and MT treatments on day 60 ranged from 9-243 $\mu \mathrm{m}$ and were higher than control. In the second experiment, egg diameter on day 30 for control ranged from 9-144 $\mu \mathrm{m}$, hCG treatment ranged from 9-441 $\mu \mathrm{m}$, while Ovaprim ranged from 9-111 $\mu \mathrm{m}$. Blood glucose, blood cholesterol, testosterone and estradiol hormone level in the first and second experiment showed no significant differences. The results showed that estradiol-17 $\beta$ and $17 \alpha$-methyltestosterone induction in $9-14.7 \mathrm{~cm}$ body length mullet increased gonad maturity to stage II while hCG induction in $10-31 \mathrm{~cm}$ body length mullet increased gonad maturity to stage III.
\end{abstract}

Keywords: estradiol-17 $\beta$, hCG, 17 $\alpha$-methyltestosterone, Mugil dussumieri, Ovaprim

\begin{abstract}
ABSTRAK
Penelitian ini merupakan rintisan untuk menghasilkan benih ikan belanak. Penelitian ini bertujuan mengevaluasi pematangan gonad ikan belanak dengan hormon. Penelitian dilakukan dengan rancangan acak lengkap yang terdiri dari tiga perlakuan dan tiga kali ulangan. Terdapat dua percobaan berbeda dengan hormon berbeda. Percobaan pertama menggunakan ikan berukuran 9-14,7 cm dengan hormon $17 \alpha$-metiltestosteron (MT) $4 \mathrm{mg} / \mathrm{kg}$, estradiol$17 \beta$ (E2) $0,07 \mathrm{mg} / \mathrm{kg}$ dan kontrol larutan fisiologis $0,9 \%$ 0,5 ml/kg. Percobaan kedua menggunakan ikan berukuran 10-31 cm dengan human chorionic gonadotropin (hCG) $750 \mathrm{IU} / \mathrm{kg}$, Ovaprim $0,5 \mathrm{ml} / \mathrm{kg}$ dan kontrol larutan fisiologis $0,9 \% 0,5 \mathrm{ml} / \mathrm{kg}$. Nilai gonadosomatic index (GSI) percobaan pertama pada hari ke-60 menunjukkan perlakuan E2 lebih tinggi dibandingkan MT dan kontrol. Hasil percobaan kedua pada hari ke-60 nilai GSI menunjukkan bahwa pemberian hCG lebih tinggi dibandingkan Ovaprim dan kontrol. Sebaran frekuensi diameter telur pada percobaan pertama untuk kontrol hari ke-30 menunjukkan kisaran 9-144 $\mu$ m. Sebaran jumlah diameter telur untuk ES dan MT hari ke-60 menunjukkan kisaran yang lebih banyak dibandingkan kontrol. Sebaran frekuensi diameter telur pada percobaan kedua untuk kontrol hari ke-30 menunjukkan kisaran 9-144 $\mu \mathrm{m}$, hCG 9-441 $\mu \mathrm{m}$ sedangkan Ovaprim 9-111 $\mu \mathrm{m}$. Kadar glukosa darah, kolesterol darah, hormon testosteron dan estradiol pada percobaan pertama dan kedua tidak menunjukkan perbedaan nyata. Hasil penelitian menunjukkan induksi hormon estradiol$17 \beta$ dan 17 $\alpha$-metiltestosteron pada ikan berukuran 9-14,7 cm dapat meningkatkan kematangan gonad mencapai TKG II sedangkan induksi hormon hCG pada ikan berukuran 10-31 cm dapat meningkatkan kematangan gonad mencapai TKG III.
\end{abstract}




\section{INTRODUCTION}

Mullet (Mugil dussumieri) from the mugilidae family has the prospect of being cultivated in the tropics. Mullets have widely geographical distribution and catadromous, adaptability in a variety of salinity, temperature, various foods, habitats and have rapid growth and are resistant to diseases (FAO, 1999). Mullet has adaptability in various environments and is suitable to the domestication of species to fresh water, brackish water and marine water (Rostami et al., 2016). Mullet is euryhaline fish that widely culture in brackish water and freshwater ponds in semiintensive culture (CMFRI, 2014; Anil et al., 2010). Mullet is a detritus feeder that efficiently obtains food on detritus and organic matter, whilst playing an important role in reducing the content of organic matter from water and pond sediments to improve water quality parameters. The feeding habits of mullet can also indirectly affect the abundance of external opportunistic parasites in shrimp such as Zoothamnium sp. and Epistylis sp., which depends on organic waste (Aghuzbeni et al., 2015; Aghuzbeni et al., 2016).

Some research has been achieved in the use of induction hormones for gonad maturation. The results of Zeinab et al. (2007) reported that GSI at a dose of 5000 IU hCG hormone induction was $0.57 \pm 0.08 \%$ while $10000 \mathrm{IU}$ hCG was 1.60 $\pm 0.45 \%$, when compared to the GSI control of $0.22 \pm 0.07 \%$, the two treatments produced a higher GSI than control. The results of Meseda et al. (2006) the dose of hCG $10000 \mathrm{IU}$ at the first injection resulted in an egg diameter ranged from 510-610 $\mu \mathrm{m}$. According to Shehadeh et al . (1973) induction of hCG at a dose of 6900 IU resulted egg diameter ranged from 520-750 $\mu \mathrm{m}$ and 440-740 $\mu \mathrm{m}$, while a dose of 8000 IU egg diameter ranged from 620-790 $\mu \mathrm{m}$. According to Sukendi et al. (2016) Ovaprim injection treatment with a dose of $0.60 \mathrm{ml} / \mathrm{kg}$ increased egg diameter $0.1925 \mathrm{~mm}$, egg maturity level $20 \%$ and GSI value of $14.75 \%$ in pawas fish (Osteochillus hasselti CV). Ovaprim is a premix product consisting of a mixture of salmon gonadotropinreleasing hormone analogue (sGnRH-a) D-Arg6Pro9-NetsGnRH-a with dopamine antagonist from domperidone type. Ovaprim is used to stimulate gonad maturation and spawning on broodstock. GnRH-a contained in Ovaprim acts to stimulate the pituitary to release gonadotropin while hCG contains FSH and LH, hCG activity is more directed to LH than FSH which can reduce aromatase activity, therefore the production of estradiol-17 $\beta$ decreased and testosterone production increased, high testosterone level can stimulating oocyte maturation, in addition to the increase in LH will increase the activity of $20 \beta$-HSD to stimulate increased production of $17 \alpha-20 \beta$ dihydroxy progesterone as a result of gonad maturation followed by oocyte ovulation (Reading \& Sullivan, 2017).

Aquaculture in Indonesia is dominated by carnivorous (shrimp and grouper) and omnivorous (tilapia and mas) fish. At present there is no detritivorous fish culture to utilize feed remnants and waste from carnivorous and omnivorous fish culture. Mullet are detritivorous fish that have the potential to be cultivated but it has not been domesticated and the fry cannot be obtained from hatchery, even though these fish can be used as environmental cleaners and sources of protein, therefore mullet has the potential to expose be a new commodity for aquaculture. The research aimed to evaluated stimulation of gonad maturation in mullet (Mugil dussumieri) using hormones.

\section{MATERIALS AND METHODS}

\section{The experiment design}

The method used for research was completely randomized design consisting of three treatments and each individual replication was repeated three times. Two experiments were conducted separately with different treatments. The first experiment treatment used the following mullet length $9-14.7 \mathrm{~cm}$ with $17 \alpha$-methyltestosterone (MT) $4 \mathrm{mg} / \mathrm{kg}$, estradiol-17 $\beta$ (E2) $0.07 \mathrm{mg} /$ $\mathrm{kg}$ and control physiological solution $0.9 \% \quad 0.5$ $\mathrm{ml} / \mathrm{kg}$, the hormone treatment usually used for stimulation of gonad maturation in fish. The second experiment treatment used the following mullet length $10-31 \mathrm{~cm}$ with human chorionic gonadotropin (hCG) $750 \mathrm{IU} / \mathrm{kg}$, Ovaprim $0.5 \mathrm{ml} /$ $\mathrm{kg}$ and control physiological solution $0.9 \% 0.5$ $\mathrm{ml} / \mathrm{kg}$, the hormone treatment usually used for stimulation of gonad maturation, ovulation and spawning in fish broodstock.

\section{The experiment implementation}

The experiment period and location

The research was conducted from March to August 2018 in UPTD PAPLWU Sungai Buntu Karawang, West Java, Fish Reproduction and Genetics Laboratory Department of Aquaculture, FPIK IPB and Laboratory of Research Institute for Ornamental Fish Culture, Depok, West Java. 


\section{Fish rearing}

The fish used were obtained from inlet and outlet drainage ponds in UPTD PAPLWU Sungai Buntu Karawang, West Java. The brackish water pond used are $1000 \mathrm{~m}^{2}$ with depth $110-120 \mathrm{~cm}$ which are equipped with six unit nets $2 \times 1$ meter. Each net contains 13 fish acclimatized to culture for 10 days. Feed given with a formulation of $32 \%$ protein content. Percentage of daily feed $1 \%$ of the body weight. The feeding frequency given twice a day at 11:00 and 17:00. Mullet cultured for 60 days. Water quality during culture is appropriate and harmless to fish (Table 1).

Table 1 . Water quality measurement

\begin{tabular}{cc}
\hline Parameters & Range \\
\hline $\mathrm{pH}$ & $8.00-9.50$ \\
Temperature $\left({ }^{\circ} \mathrm{C}\right)$ & $23.30-35.00$ \\
Salinity $(\mathrm{g} / \mathrm{L})$ & 20.00 \\
Dissolved oxygen $(\mathrm{mg} / \mathrm{L})$ & $6.60-9.50$ \\
$\mathrm{NO}_{2}^{-}(\mathrm{mg} / \mathrm{L})$ & $0.10-0.57$ \\
$\mathrm{NO}_{3}{ }^{-}(\mathrm{mg} / \mathrm{L})$ & $1.20-5.30$ \\
$\mathrm{NH}_{4}{ }^{+}(\mathrm{mg} / \mathrm{L})$ & $0.10-0.60$ \\
$\mathrm{NH}_{3}(\mathrm{mg} / \mathrm{L})$ & $0.002-0.02$ \\
Total alkalinity $(\mathrm{mg} / \mathrm{L})$ & $185.00-280.00$ \\
Total organic matter $(\mathrm{mg} / \mathrm{L})$ & $20.20-56.90$ \\
Total plankton $(\mathrm{cell} / \mathrm{ml})$ & $3.50-4.83$ \\
\hline
\end{tabular}

\section{Hormone induction}

The first step is anesthesia, the fish is given an anesthetic using a fish stabilizer at a dose of 0.3 $\mathrm{ml} / \mathrm{L}$, while the fainting fish were measured by the length and body weight. The second step is injection was carried out by determining the dose of the hormone according to the weight of the fish using a $10-100 \mu \mathrm{L}$ micropipette then injected intramuscularly into the dorsal muscle according to the treatment dose on day 0 using $1 \mathrm{ml}$ syringe. The third step is recovery, where the injected fish was put into a container with strong aeration for 10 minutes, after the fish has been recovered, put back into the nets culture.

\section{Parameter measurement}

\section{Gonadosomatic index (GSI) value}

Gonadosomatic index (GSI) is the calculation of the gonad mass as a proportion of the total body mass. The GSI propose is as an alternative way to estimate the gonad maturity. It is presented by the formula.

$$
\operatorname{GSI}(\%)=\frac{\mathrm{GW}}{\mathrm{BW}} \times 100
$$

\section{Annotation :}

$\mathrm{GW}=$ gonad weight $(\mathrm{g})$

$\mathrm{BW}=$ body weight $(\mathrm{g})$

\section{Hepatosomatic index (HSI) value}

Hepatosomatic index (HSI) is the calculation of the liver mass as a proportion of the total body mass. It is presented by the formula.

$$
\operatorname{HSI}(\%)=\frac{\mathrm{LW}}{\mathrm{BW}} \times 100
$$

Annotation :

$\mathrm{LW}=$ liver weight $(\mathrm{g})$

$\mathrm{BW}=$ body weight $(\mathrm{g})$

\section{Egg diameter measurement}

Egg diameter is determined from female fish that have stage I-III. Two hundred eggs were taken from the subgonads, which were anterior, middle,

\begin{tabular}{|c|c|c|}
\hline Stage & Male & Female \\
\hline I & $\begin{array}{l}\text { The testicles are like threads, shorter and } \\
\text { visible in the abdominal cavity, transparent. }\end{array}$ & $\begin{array}{l}\text { The ovaries are like threads, long to the front of the } \\
\text { abdominal cavity, transparent, slippery surfaces. }\end{array}$ \\
\hline II & $\begin{array}{l}\text { The size of testis is larger, the color white like } \\
\text { milk, the shape is clearer than stage I. }\end{array}$ & $\begin{array}{l}\text { The size of ovary is larger, the color is yellowish, } \\
\text { the eggs are not clearly visible with the eyes. }\end{array}$ \\
\hline III & $\begin{array}{l}\text { The surface of the testicles is jagged, the colors } \\
\text { are whiter and bigger. In the circumstances } \\
\text { preserved the testicles easily break. }\end{array}$ & $\begin{array}{l}\text { Ovaries are yellow, the eggs are clearly visible to } \\
\text { the eye. }\end{array}$ \\
\hline IV & $\begin{array}{l}\text { Like stage III the testicles appear clearer and } \\
\text { more dense. }\end{array}$ & $\begin{array}{l}\text { Ovaries grow, eggs are yellow, easily separated, } \\
\text { oil grains are not visible. Ovaries fill half to two } \\
\text { per third of the abdominal cavity and intestines are } \\
\text { pressed. }\end{array}$ \\
\hline V & $\begin{array}{l}\text { The anterior of the test is deflated and the near } \\
\text { part of the discharge contains }\end{array}$ & $\begin{array}{l}\text { Ovaries are wrinkled, thick walls, remaining eggs } \\
\text { are located near the release, many eggs like stage II }\end{array}$ \\
\hline
\end{tabular}

Table 2. Gonad maturity stage in mullet (M. dussumieri) 
Table 3. GSI and HSI first experiment

\begin{tabular}{ccccc}
\hline Parameter & Measurement & \multicolumn{1}{l}{ Control } & estradiol-17 $\beta$ & $17 \alpha-$ methyltestosterone \\
\hline & Day 0 & $0.00 \pm 0.00^{\mathrm{a}}$ & $0.36 \pm 0.20^{\mathrm{ab}}$ & $0.43 \pm 0.22^{\mathrm{ab}}$ \\
GSI (\%) & Day 30 & $0.19 \pm 0.19^{\mathrm{ab}}$ & $0.11 \pm 0.11^{\mathrm{ab}}$ & $0.17 \pm 0.03^{\mathrm{ab}}$ \\
& Day 60 & $0.54 \pm 0.20^{\mathrm{ab}}$ & $1.31 \pm 0.94^{\mathrm{b}}$ & $1.00 \pm 0.51^{\mathrm{ab}}$ \\
\hline & Day 0 & $2.74 \pm 0.10^{\mathrm{c}}$ & $2.38 \pm 0.32^{\mathrm{c}}$ & $2.12 \pm 0.33^{\mathrm{bc}}$ \\
HSI (\%) & Day 30 & $0.97 \pm 0.21^{\mathrm{a}}$ & $0.76 \pm 0.19^{\mathrm{a}}$ & $1.13 \pm 0.20^{\mathrm{a}}$ \\
& Day 60 & $0.60 \pm 0.28^{\mathrm{a}}$ & $1.27 \pm 0.58^{\mathrm{ab}}$ & $1.24 \pm 0.24^{\mathrm{ab}}$ \\
\hline
\end{tabular}

Note : Different letters on the same line show significant difference affects $(\mathrm{P}<0.05)$. The values listed are mean $\pm \mathrm{SE}$.

Table 4. GSI and HSI second experiment

\begin{tabular}{lllll}
\hline Parameter & Measurement & Control & hCG & Ovaprim \\
\hline \multirow{3}{*}{ GSI (\%) } & Day 0 & $0.42 \pm 0.11^{\mathrm{a}}$ & $1.63 \pm 1.16^{\mathrm{a}}$ & $0.74 \pm 0.07^{\mathrm{a}}$ \\
& Day 30 & $0.28 \pm 0.17^{\mathrm{a}}$ & $2.53 \pm 2.07^{\mathrm{a}}$ & $0.88 \pm 0.33^{\mathrm{a}}$ \\
& Day 60 & $6.72 \pm 0.32^{\mathrm{b}}$ & $7.18 \pm 0.59^{\mathrm{c}}$ & $3.29 \pm 2.66^{\mathrm{ab}}$ \\
\hline \multirow{3}{*}{ HSI (\%) } & Day 0 & $1.27 \pm 0.58^{\mathrm{a}}$ & $1.49 \pm 0.50^{\mathrm{a}}$ & $1.45 \pm 0.79^{\mathrm{a}}$ \\
& Day 30 & $0.67 \pm 0.08^{\mathrm{a}}$ & $0.75 \pm 0.23^{\mathrm{a}}$ & $0.82 \pm 0.12^{\mathrm{a}}$ \\
& Day 60 & $1.22 \pm 0.20^{\mathrm{a}}$ & $1.41 \pm 0.10^{\mathrm{a}}$ & $1.18 \pm 0.21^{\mathrm{a}}$ \\
\hline
\end{tabular}

Note : Different letters on the same line show significant difference affects $(\mathrm{P}<0.05)$. The values listed are mean \pm SE.

and posterior respectively. Egg sampling was carried out on the day 0,30 and 60 . Measurement of egg diameter using a microscope was equipped with an ocular micrometer that has been tuned in advance with an objective micrometer $10 \times 10$ magnification, it was measured using IMAGE-J v1.48 software (National Institute of Health, USA).

\section{Gonad maturity stage analysis}

Gonad maturity stage is a grouping of gonad maturity of fish based on changes that occur in the gonads. Gonad maturity stage in mullet is shown in Table 2.

\section{Gonad and liver histology}

Testing the effect of hormonal stimulation on gonad and liver cell development was carried out through histological observations. Gonad and liver samples was carried out on the day 0,30 , and 60 . The gonads and livers were fixed using a $10 \%$ buffer neutral formalin (BNF) fixation solution for 1-2 days. Histological preparation was carried out through stages of fixation, dehydration, clearing, embedding, deparaffination, staining of preparations, and dehydration. The gonads and livers were trimmed treatment and put into plastic tapes to make wax blocks. The wax blocks formed were cut using a microtome machine and placed in a glass object then hematoxylin eosin
(HE) staining was done. Histology observation using a microscope was equipped with an ocular micrometer that has been tuned in advance with an objective micrometer 10×40 magnification.

\section{Blood glucose level and blood cholesterol level measurement}

Blood glucose and blood cholesterol levels were analyzed using easy-touch kit, by way of paper strips inserted into the easy-touch kit hole, wait a while until the monitor screen displays a choice of blood unit components (mmol/L or $\mathrm{mg} / \mathrm{dL}$ ), taking blood for 3 samples of test fish in each treatment, on the day 0,30 and 60. Blood was dropped on a paper strip that has been installed on the easy-touch kit, waiting until the monitor displays the results according to the unit selected. According to Bartoňková et al. (2016), measuring using a kit was easier and faster with results whose accuracy was not much different from conventional methods, such as spectrophotometers.

Testosterone and estradiol hormone level measurement

Blood plasma was collected from 3 samples of fish in each treatment. Blood plasma was carried out on the day 0,30 and 60 . Anesthetically fish using a fish stabilizer at a dose of $0.3 \mathrm{ml} / \mathrm{L}$ then blood was taken from the arteries at the base of the 
tail as much as $1 \mathrm{ml}$ using a $3 \mathrm{ml}$ volume syringe that has been given anticoagulants (solution of citrate phosphate dextrose), then centrifuged at $5000 \mathrm{rpm}$ for 15 minutes, blood plasma was taken and stored in a freezer at $-20^{\circ} \mathrm{C}$ and then measured using the Vidas ELISA kit for estradiol (EIA-2693) and testosterone (EIA-1559), then data was analyzed using program Gen 5 (BioTek ${ }^{\circledR}$ Instruments, Inc.).

\section{Data analysis}

The egg diameter, gonad maturity stage, gonad, and liver histology were explained descriptively. Parameters measurement include gonadosomatic index (GSI) value, hepatosomatic index (HSI) value, blood glucose level, blood cholesterol level, testosterone and estradiol hormone level were analyzed statistically using analysis of variance (ANOVA) using the SPSS version 16 program with Duncan's test.

\section{RESULTS AND DISCUSSIONS}

\section{Gonadosomatic index (GSI) value and hepatosomatic index (HSI) value}

GSI value of the first experiment on day 0 and 30 showed no significant difference, however on day 60 GSI of estradiol-17 $\beta$ treatment $(1.31 \pm$ $0.94 \%$ ) was higher than $17 \alpha$-methyltestosterone $(1.00 \pm 0.51 \%)$ and control $(0.54 \pm 0.20 \%)$. Overall the GSI value in all treatments showed oocyte development from day 0 to day 60 . The HSI value of the first experiment on day 30 and 60 showed no significant difference, however HSI value for day 0 was higher than day 30 and 60, result is shown in Table 3.

In the second experiment on day 0 and $30 \mathrm{GSI}$ value showed no significant difference, however on day 60 GSI value of $\mathrm{hCG}$ treatment $(7.18 \pm$ $0.59 \%)$ was higher than Ovaprim $(3.29 \pm 2.66 \%)$ and control $(6.72 \pm 0.32 \%)$. Overall the GSI value in all treatments showed oocyte development from day 0 to day 60 . In the second experiment, HSI value for day 0,30 and 60 showed no significant difference, however HSI value on day 30 decreased and then on the day 60 increased again, result is shown in Table 4. hCG, $17 \alpha$-methyltestosterone and estradiol-17 $\beta$ hormone can increase level of estradiol-17 $\beta$ hormone in the blood due to the work activity of the hormone FSH (GtH-1). According to Reading and Sullivan (2017) follicle stimulating hormone (FSH) will stimulate theca cells to release testosterone hormone which in turn stimulates granulosa cells to produce estradiol-
$17 \beta$ hormone. The theca cell layer is affected by gonadotropin to produce testosterone. In granulosa cells, testosterone is converted to estradiol-17 $\beta$ by aromatase enzyme. The resulting estradiol- $17 \beta$ is released into the blood then stimulates the liver to carry out vitellogenin synthesis. Vitellogenin is then released back into the blood and will be selectively absorbed by oocytes. The results of vitellogenesis will result in the development of egg diameter and gonad. Vitellogenesis is affected by endogenous and environmental factors such as food, seasonal changes and temperature. The results showed that the GSI and HSI values in the first experiment and the second experiment showed an inverse relationship, if the HSI value increases the GSI value decreases. The HSI value increases because the dose in the treatment is the most appropriate amount to increase the content of gonadotropins secreted by the pituitary, then gonadotropin will stimulate the theca cell layer to produce testosterone. Inside the granulosa layer the testosterone hormone is converted by the aromatase enzyme to estradiol-17 $\beta$. The increased level of estradiol-17 $\beta$ in the granulosa layer will stimulate liver to increase vitellogenin synthesis. This activity will increase the value of the HSI (Reading \& Sullivan 2017; Mujtahidah et al., 2016). At the growth stage of hepatocyte cytoplasm, female fish accumulates by granulosa. Nucleus is found in the middle of hepatocytes. Sinusoid endothelium appears between hepatocytes. During the maturation period, the yolk deposition stage occurs in hepatocytes characterized by enlarged size of hepatocytes and increased basophilic cytoplasmic granules, and nucleoli undergo hypertrophy. Hepatocyte binucleate was found to increase and sinusoids with well vascularization (Chakrabarti \& Chatterjee, 2014; Rajeshkumar, 2015, Abdallah et al., 2013; Pinto et al., 2010; Tayel et al., 2014; Yilmaz et al., 2016). GSI and HSI in Mullet fish has fluctuative value based on spesies and location (Abdalhafid \& El-Mor, 2014; El-Halfawy et al., 2007; El-Boray et al., 2012; Ghaninejad et al., 2010; Hashemi et al., 2012; Karim, 2017; Maryam et al., 2011; Nahdi et al., 2008; Sulistiono et al., 2001; Mokhtar et al., 2015; Saoudi \& Aun., 2014; Wigati \& Syafei., 2013; Yones et al., 2016).

\section{Egg diameter, gonad maturity stage, gonad and liver histology}

Egg diameter, gonad maturity stage, gonad and liver histology in first experiment are presented in Figure 1, Figure 3 and Table 5 while in second 


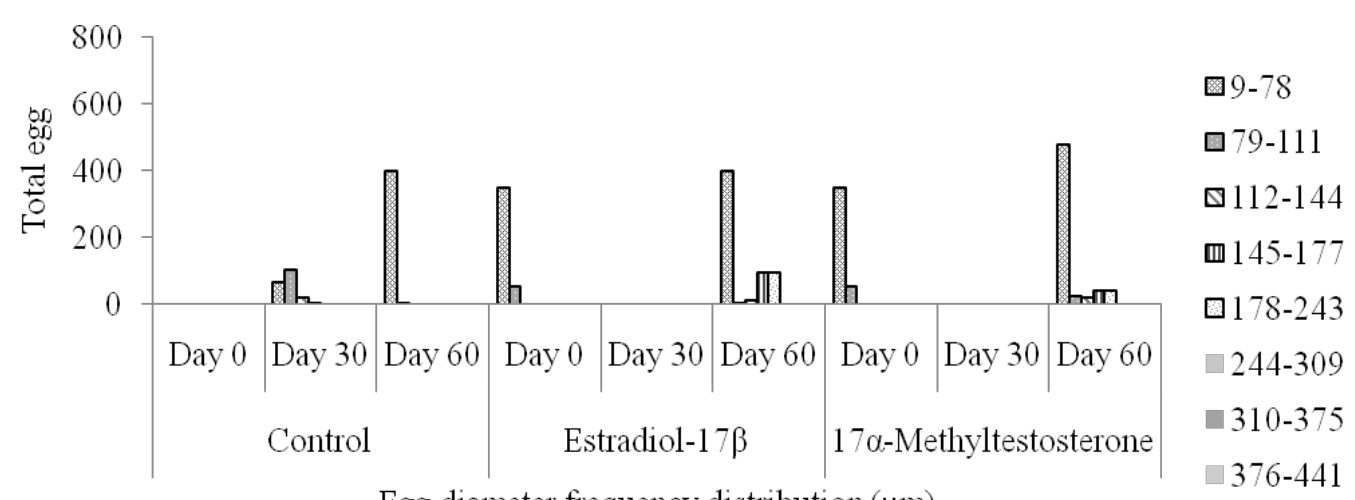

Egg diameter frequency distribution $(\mu \mathrm{m})$

Figure 1. Egg diameter frequency distribution first experiment

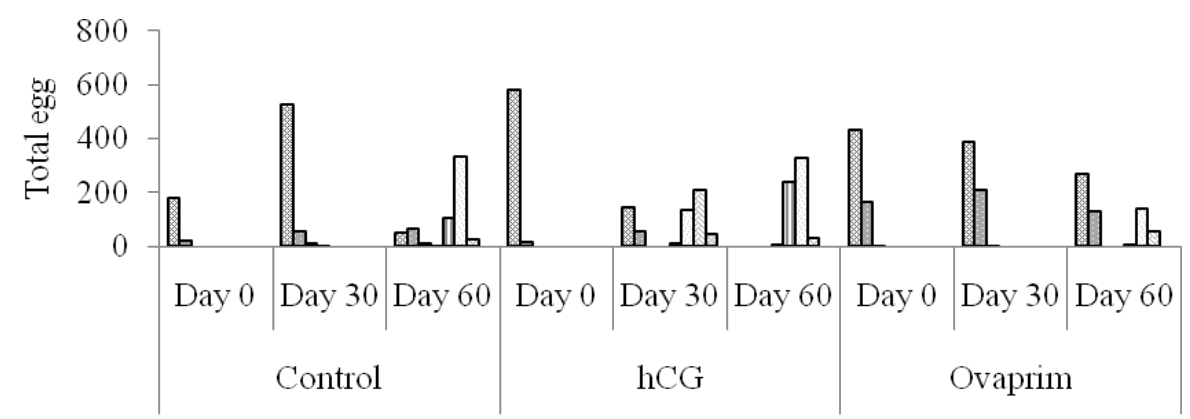

$\square 9-78$

$\square 79-111$

ब $112-144$

닌 1457

四 178-243

口244-309

$\square 310-375$

Egg diameter frequency distribution $(\mu \mathrm{m})$

Figure 2. Egg diameter frequency distribution second experiment

Table 5. Gonad maturity stage and oocyte development first experiment

\begin{tabular}{|c|c|c|c|c|c|c|c|c|c|c|}
\hline \multirow[b]{2}{*}{ TKG } & \multirow[b]{2}{*}{$\begin{array}{c}\text { Oocyte } \\
\text { development (\%) }\end{array}$} & \multicolumn{3}{|c|}{ Control } & \multicolumn{3}{|c|}{ Estradiol-17 $\beta$} & \multicolumn{3}{|c|}{$17 \alpha-$ Methyltestosterone } \\
\hline & & Day 0 & Day 30 & Day 60 & Day 0 & Day 30 & Day 60 & Day 0 & Day 30 & $\begin{array}{c}\text { Day } \\
60\end{array}$ \\
\hline $\mathrm{I}$ & Oogonia & 100 & 100 & 100 & 33.33 & 100 & 33.33 & 33.33 & 100 & NF \\
\hline \multirow{2}{*}{ II } & $\begin{array}{c}\text { Early } \\
\text { perinucleolus }\end{array}$ & NF & NF & $\mathrm{NF}$ & 66.66 & NF & 33.33 & 66.66 & $\mathrm{NF}$ & 66.66 \\
\hline & $\begin{array}{l}\text { Late } \\
\text { perinucleolus }\end{array}$ & NF & NF & NF & NF & NF & 33.33 & NF & $\mathrm{NF}$ & 33.33 \\
\hline \multirow{2}{*}{ III } & Vaculization & NF & NF & $\mathrm{NF}$ & NF & NF & $\mathrm{NF}$ & $\mathrm{NF}$ & $\mathrm{NF}$ & NF \\
\hline & Viteliogenic & $\mathrm{NF}$ & $\mathrm{NF}$ & $\mathrm{NF}$ & $\mathrm{NF}$ & $\mathrm{NF}$ & $\mathrm{NF}$ & $\mathrm{NF}$ & $\mathrm{NF}$ & $\mathrm{NF}$ \\
\hline IV & $\begin{array}{c}\text { Germinal vesicle } \\
\text { migration }\end{array}$ & NF & NF & NF & NF & NF & NF & $\mathrm{NF}$ & $\mathrm{NF}$ & NF \\
\hline $\mathrm{V}$ & Mature yolk & NF & $\mathrm{NF}$ & NF & $\mathrm{NF}$ & NF & $\mathrm{NF}$ & NF & $\mathrm{NF}$ & $\mathrm{NF}$ \\
\hline
\end{tabular}

experiment are presented in Figure 2, Figure 4 and Table 6.

In the first experiment egg diameter on day 30 for control showed ranged from 9-144 $\mu \mathrm{m}$ while on day 60 decreased. Egg diameter in estradiol$17 \beta$ and $17 \alpha$-methyltestosterone treatment on day 60 showed ranged from 9-243 $\mu \mathrm{m}$. estradiol$17 \beta$ treatment on day 60 had larger size than $17 \alpha$-methyltestosterone and control. In the second experiment egg diameter for hCG treatment on day 30 showed ranged from 9-441 $\mu$ m while Ovaprim on day 30 showed ranged from 9-111 $\mu \mathrm{m}$. Control on day 30 showed ranged from 9-144 $\mu \mathrm{m}$. hCG treatment had larger size than Ovaprim. hCG hormone can increase egg diameter. hCG contains the estradiol-17 $\beta$ hormone which can stimulate vitelogenesis. Vitelogenesis is the process of induction and synthesis of vitelogenin in the liver in response to estradiol-17 $\beta$ hormone. Vitelogenin produced by liver is released into the 


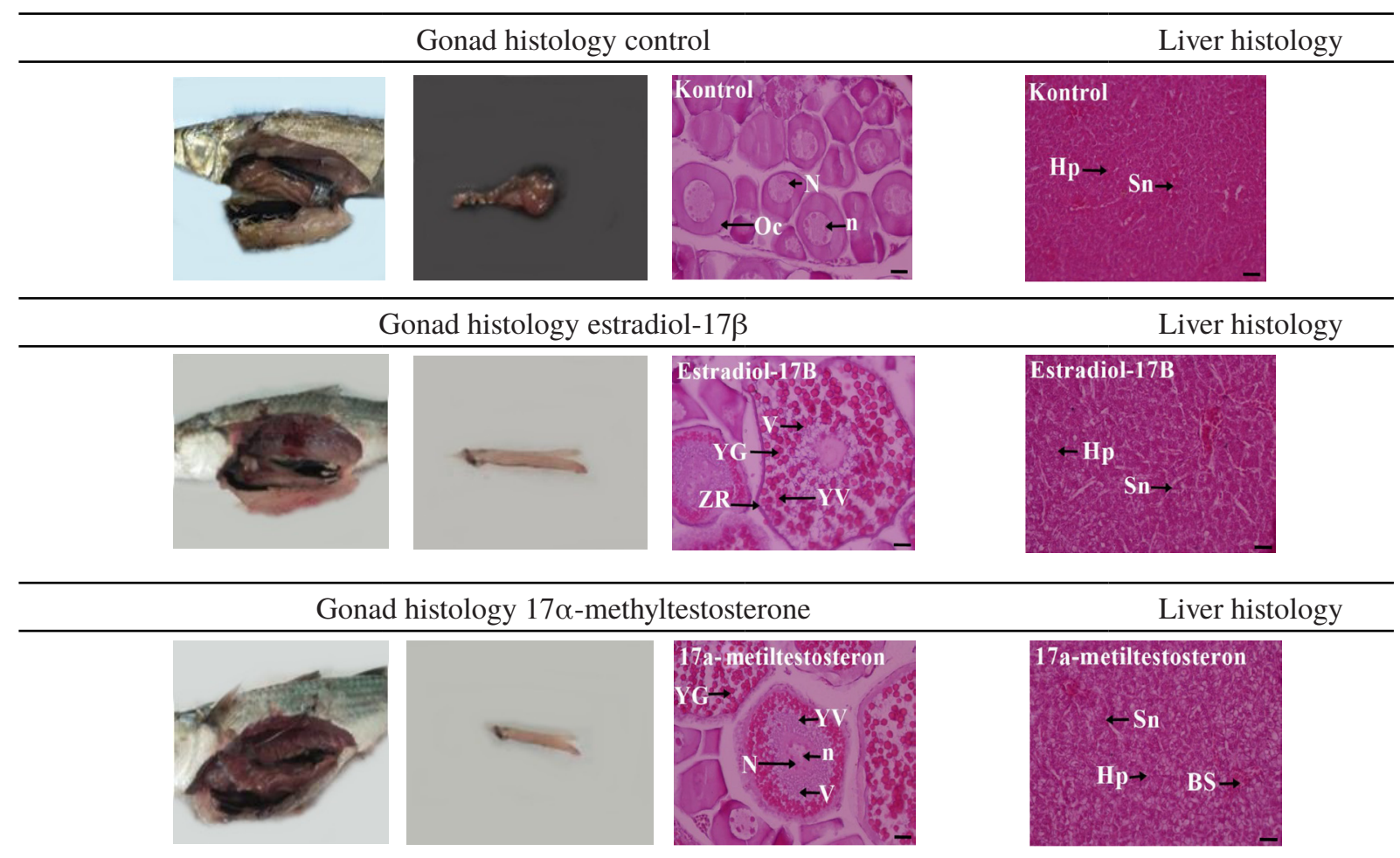

Figure 3. Gonad and liver histology in first experiment on day 60. Gonad histology : oogonia $(\mathrm{Og})$, oocyte $(\mathrm{Oc})$, basofilic cytoplasm (BC), nucleus (N), nucleolei (n), vesicle (V), yolk vesicel (YV), yolk globule (YG), radiate zone (ZR) and epitel folikel (EF). Liver histology : hepatocyte (Hp), sinusoid (Sn), blood sinus (BS). (HE) x 400.

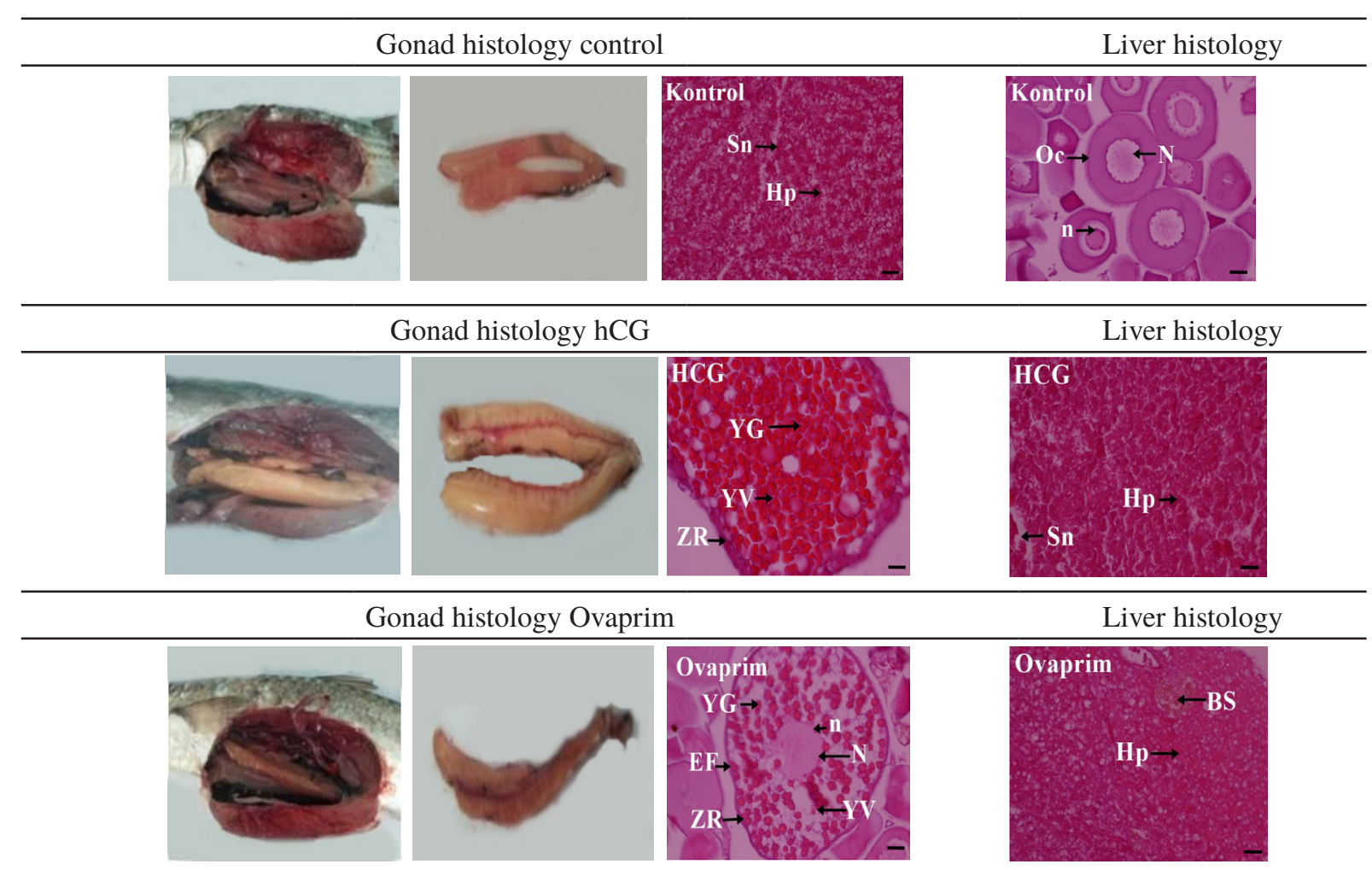

Figure 4. Gonad and liver histology in second experiment on day 30. Gonad histology : oogonia (Og), oocyte (Oc), basofilic cytoplasm (BC), nucleus $(\mathrm{N})$, nucleolei $(\mathrm{n})$, vesicle $(\mathrm{V})$, yolk vesicle (YV), yolk globule (YG), radiate zone (ZR) and epitel folikel (EF). Liver histology : hepatocyte (Hp), sinusoid (Sn), blood sinus (BS). (HE) x 400. 
Table 6. Gonad maturity stage and oocyte development second experiment

\begin{tabular}{|c|c|c|c|c|c|c|c|c|c|c|}
\hline \multirow[b]{2}{*}{$\mathrm{TKG}$} & \multirow{2}{*}{$\begin{array}{c}\text { Oocyte } \\
\text { development }(\%)\end{array}$} & \multicolumn{3}{|c|}{ Control } & \multicolumn{3}{|c|}{$\mathrm{hCG}$} & \multicolumn{3}{|c|}{ Ovaprim } \\
\hline & & $\begin{array}{c}\text { Day } \\
0\end{array}$ & $\begin{array}{c}\text { Day } \\
30\end{array}$ & Day 60 & Day 0 & Day 30 & Day 60 & Day 0 & Day 30 & Day 60 \\
\hline I & Oogonia & 66.66 & $\mathrm{NF}$ & $\mathrm{NF}$ & $\mathrm{NF}$ & $\mathrm{NF}$ & $\mathrm{NF}$ & NF & $\mathrm{NF}$ & $\mathrm{NF}$ \\
\hline \multirow{2}{*}{ II } & Early perinucleolus & 33.33 & 66.66 & $\mathrm{NF}$ & 100 & 33.33 & NF & 100 & 100 & 66.66 \\
\hline & Late perinucleolus & $\mathrm{NF}$ & 33.33 & NF & $\mathrm{NF}$ & $\mathrm{NF}$ & $\mathrm{NF}$ & NF & $\mathrm{NF}$ & $\mathrm{NF}$ \\
\hline \multirow{2}{*}{ III } & Vaculization & $\mathrm{NF}$ & $\mathrm{NF}$ & $\mathrm{NF}$ & $\mathrm{NF}$ & $\mathrm{NF}$ & $\mathrm{NF}$ & NF & $\mathrm{NF}$ & $\mathrm{NF}$ \\
\hline & Viteliogenic & $\mathrm{NF}$ & NF & 100 & NF & 66.66 & 100 & NF & NF & 33.33 \\
\hline IV & $\begin{array}{c}\text { Germinal vesicle } \\
\text { migration }\end{array}$ & NF & NF & NF & $\mathrm{NF}$ & NF & $\mathrm{NF}$ & NF & $\mathrm{NF}$ & $\mathrm{NF}$ \\
\hline $\mathrm{V}$ & Mature yolk & NF & $\mathrm{NF}$ & $\mathrm{NF}$ & $\mathrm{NF}$ & NF & $\mathrm{NF}$ & $\mathrm{NF}$ & $\mathrm{NF}$ & $\mathrm{NF}$ \\
\hline
\end{tabular}

Note : NF (Not Found).

Table 7. First experiment

\begin{tabular}{|c|c|c|c|c|}
\hline Parameter & Measurement & Control & estradiol-17 $\beta$ & $17 \alpha$-methyltestosterone \\
\hline \multirow{3}{*}{$\begin{array}{l}\text { Blood glucose } \\
(\mathrm{mmol} / \mathrm{L})\end{array}$} & Day 0 & $1.10 \pm 0.00^{a}$ & $1.10 \pm 0.00^{\mathrm{a}}$ & $1.10 \pm 0.00^{\mathrm{a}}$ \\
\hline & Day 30 & $1.10 \pm 0.00^{\mathrm{a}}$ & $1.25 \pm 0.15^{\mathrm{a}}$ & $1.39 \pm 0.29^{a}$ \\
\hline & Day 60 & $1.40 \pm 0.30^{\mathrm{a}}$ & $1.10 \pm 0.00^{\mathrm{a}}$ & $1.10 \pm 0.00^{\mathrm{a}}$ \\
\hline \multirow{3}{*}{$\begin{array}{l}\text { Blood cholesterol } \\
\quad(\mathrm{mmol} / \mathrm{L})\end{array}$} & Day 0 & $18.17 \pm 0.43^{\mathrm{d}}$ & $13.39 \pm 2.25^{\mathrm{c}}$ & $7.16 \pm 2.92^{\mathrm{b}}$ \\
\hline & Day 30 & $2.50 \pm 0.00^{\mathrm{a}}$ & $2.50 \pm 0.00^{\mathrm{a}}$ & $2.50 \pm 0.00^{\mathrm{a}}$ \\
\hline & Day 60 & $2.50 \pm 0.00^{a}$ & $2.50 \pm 0.00^{\mathrm{a}}$ & $2.50 \pm 0.00^{a}$ \\
\hline \multirow{3}{*}{$\begin{array}{l}\text { Testosterone hormone } \\
\qquad(\mathrm{pg} / \mathrm{ml})\end{array}$} & Day 0 & $593 \pm 61.33^{\mathrm{a}}$ & $699 \pm 46.91^{\mathrm{a}}$ & $581 \pm 70.82^{a}$ \\
\hline & Day 30 & $593 \pm 37.60^{a}$ & $568 \pm 51.38^{\mathrm{a}}$ & $636 \pm 93.99^{a}$ \\
\hline & Day 60 & $532 \pm 63.51^{\mathrm{a}}$ & $554 \pm 35.93^{\mathrm{a}}$ & $633 \pm 111.95^{\mathrm{a}}$ \\
\hline \multirow{3}{*}{$\begin{array}{l}\text { Estradiol hormone } \\
\qquad(\mathrm{pg} / \mathrm{ml})\end{array}$} & Day 0 & $67.89 \pm 2.70^{\mathrm{a}}$ & $75.19 \pm 10.83^{\mathrm{a}}$ & $68.08 \pm 17.23^{\mathrm{a}}$ \\
\hline & Day 30 & $52.46 \pm 5.31^{\mathrm{a}}$ & $48.87 \pm 5.67^{\mathrm{a}}$ & $58.31 \pm 8.00^{\mathrm{a}}$ \\
\hline & Day 60 & $51.17 \pm 4.17^{\mathrm{a}}$ & $58.72 \pm 11.14^{\mathrm{a}}$ & $63.46 \pm 7.33^{\mathrm{a}}$ \\
\hline
\end{tabular}

Note : Different letters on the same line show significant difference affects $(\mathrm{P}<0.05)$. The values listed are mean \pm SE.

Table 8. Second experiment

\begin{tabular}{|c|c|c|c|c|}
\hline Parameter & Measurement & Control & hCG & Ovaprim \\
\hline \multirow{3}{*}{$\begin{array}{l}\text { Blood glucose } \\
\quad(\mathrm{mmol} / \mathrm{L})\end{array}$} & Day 0 & $1.10 \pm 0.00^{\mathrm{a}}$ & $1.10 \pm 0.00^{\mathrm{a}}$ & $1.10 \pm 0.00^{\mathrm{a}}$ \\
\hline & Day 30 & $1.16 \pm 0.06^{\mathrm{ab}}$ & $1.42 \pm 0.29^{\mathrm{ab}}$ & $2.13 \pm 0.13^{\mathrm{c}}$ \\
\hline & Day 60 & $1.75 \pm 0.33^{\mathrm{bc}}$ & $1.23 \pm 0.13^{\mathrm{ab}}$ & $1.73 \pm 0.32^{\mathrm{abc}}$ \\
\hline \multirow{3}{*}{$\begin{array}{l}\text { Blood cholesterol } \\
(\mathrm{mmol} / \mathrm{L})\end{array}$} & Day 0 & $7.62 \pm 5.12^{\mathrm{a}}$ & $7.44 \pm 4.94^{\mathrm{a}}$ & $4.79 \pm 2.29^{a}$ \\
\hline & Day 30 & $2.50 \pm 0.00^{a}$ & $4.09 \pm 1.59^{a}$ & $4.09 \pm 1.59^{\mathrm{a}}$ \\
\hline & Day 60 & $5.68 \pm 1.62^{\mathrm{a}}$ & $3.72 \pm 1.22^{\mathrm{a}}$ & $5.63 \pm 1.62^{\mathrm{a}}$ \\
\hline \multirow{3}{*}{$\begin{array}{l}\text { Testosterone hormone } \\
\qquad(\mathrm{pg} / \mathrm{ml})\end{array}$} & Day 0 & $619 \pm 97.49^{\mathrm{ab}}$ & $622 \pm 37.17^{\mathrm{ab}}$ & $701 \pm 49.62^{c}$ \\
\hline & Day 30 & $580 \pm 38.95^{\mathrm{ab}}$ & $425 \pm 89.79^{\mathrm{ab}}$ & $382 \pm 38.91^{\mathrm{a}}$ \\
\hline & Day 60 & $684 \pm 113.17^{\mathrm{ab}}$ & $616 \pm 83.69^{\mathrm{ab}}$ & $679 \pm 177.91^{\mathrm{ab}}$ \\
\hline \multirow{3}{*}{$\begin{array}{l}\text { Estradiol hormone } \\
\qquad(\mathrm{pg} / \mathrm{ml})\end{array}$} & Day 0 & $48.30 \pm 7.35^{\mathrm{a}}$ & $32.35 \pm 12.71^{\mathrm{a}}$ & $35.85 \pm 9.36^{a}$ \\
\hline & Day 30 & $42.91 \pm 7.02^{\mathrm{a}}$ & $47.79 \pm 21.26^{\mathrm{a}}$ & $58.40 \pm 11.59^{\mathrm{a}}$ \\
\hline & Day 60 & $611.02 \pm 71.07^{\mathrm{b}}$ & $129.03 \pm 72.58^{a}$ & $83.13 \pm 21.95^{\circ}$ \\
\hline
\end{tabular}

Note : Different letters on the same line show significant difference affects $(\mathrm{P}<0.05)$. The values listed are mean \pm SE. 
circulatory system, then selectively absorbed by oocyte to accumulate into the yolk in the form of lipovitelin and fosvitin. Vitelogenin absorption activity by oocytes causes the egg diameter to increase (Reading \& Sullivan, 2017; Isriansyah, 2011; Nuraini et al., 2012; Suriansyah et al., 2011; Yousefian et al., 2009; Putra \& Razai, 2017). The results of measurement egg diameter in the Ovaprim treatment increased but when compared to hCG and control was lower. According to Sukendi et al. (2016); Adebiyi et al. (2013); Ali et al. (2015); Aziz \& Kaleseran (2017); Jhajharia (2011); Marimuthu et al. (2015); Mousavi \& Yousefian (2012); Muchlisin et al. (2014); Okere et al. (2015); Rachimi et al. (2015); Rehman et al. (2015); Ghanemi \& Khodadadi (2017); Rawat et al, (2017); Acharjee et al. (2017); AchionyeNzeh \& Obaroh (2012) Ovaprim treatment can produce larger diameter eggs. Increased egg diameter is thought to occur because the FSH content increases so that the follicle develops and egg diameter increases.

The stage of oocyte development includes the oogonia stage characterized by small round cells with relatively cytoplasmic clear zone. Oogonia was occurred either solitary or small nests with cell diameter ranged from 10-15 $\mu \mathrm{m}$. It was weakly basophilic cells with a size larger than the nucleus, nucleus diameter varying from 8-13 $\mu \mathrm{m}$. The early perinucleolus stage was mostly polygonal oocytes and sizes from 17-38 $\mu \mathrm{m}$. The nucleus diameter is $12-32 \mu \mathrm{m}$. Homogeneous and strongly basophilic cytoplasm is clearly seen. The oocyte membrane was not yet differentiated. Nuclei were arranged in the periphery of the nucleus and varyinacharjeeg number from 2-5. The late perinucleolus stage is the last stage in the immaturation period, the oocyte diameter reached to $150 \mu \mathrm{m}$. The nucleus size reached to $50 \mu \mathrm{m}$ with a numerous number of nucleolei 7-11. The nucleolei arranged in the periphery of the nucleus. The maturation period includes four stages. The first stage is vaculization, characterized by yolk vesicles in the cytoplasm. The vesicle structure appeared empty. Oocyte reached to $150 \mu \mathrm{m}$. Nuclear diameter ranged from 60-90 $\mu \mathrm{m}$. At the end of this stage the yolk vesicle diameter reached to $23 \mu \mathrm{m}$. The yolk vesicles were few in number and appeared in the periphery of the cytoplasm. The oocytes were surrounded by zone radiate of about $3 \mu \mathrm{m}$ in thickness coated with a follicular epithelial layer of $1 \mu \mathrm{m}$. The second stage is vitellogenic, this stage is a accumulation proceeded rapidly of yolk and oocyte diameter ranged to $400 \mu \mathrm{m}$ and the nucleus appeared with diameter $98 \mu \mathrm{m}$ in average. The yolk granules ware densely packed and occupied mostly the total volume of the cytoplasm of oocyte. The zone radiate increased in thickness varying from 4-9 $\mu \mathrm{m}$ and follicular epithelial layer was $4.5 \mu \mathrm{m}$. Vacuoles diameter ranged from 2-10 $\mu \mathrm{m}$ (ElHalfawy et al., 2007; Al bieri \& Araújo., 2010; Vazirzadeh \& Ezhdehakoshpour, 2014; Mousa, 2010). The third stage germinal vesicle migration and fourth stage of mature yolk were not found in the experiment.

\section{Blood glucose level, blood cholesterol level, testosterone and estradiol hormone level}

Blood glucose level and blood cholesterol level, testosterone and estradiol hormone level on day 0,30 and 60 in first experiment are shown in Table 7.

Blood glucose level and blood cholesterol level, testosterone and estradiol hormone level on day 0,30 and 60 in second experiment are shown in Table 8.

In the firstexperiment, glucose level of estradiol$17 \beta$ and $17 \alpha$-methyltestosterone treatment on day 0,30 and 60 showed no significant difference. However glucose level on day 30 increased then on day 60 decreased. In the second experiment, glucose level of hCG and Ovaprim on day 0 showed no significant difference. Glucose level on day 30 in Ovaprim treatment was higher than hCG treatment and control. Glucose level on day 60 in Ovaprim treatment decreased. Increased glucose level is indicated release of glucose into bloodstream which will be used to high energy requirements for oocyte development in gonad. Decreasing glucose level is a signal to synthesize and secrete glucagon. Glucose level according to El-Shafei (2017) for 7 days $(17.25 \pm 2.08 \mathrm{mg} / \mathrm{dL})$, 14 days $(17.6 \pm 18 \mathrm{mg} / \mathrm{dL})$ and 21 days $(17.4 \pm 18$ $\mathrm{mg} / \mathrm{dL}$ ) while according to Rakovac et al. (2008) mean $7.86 \mathrm{mmol} / \mathrm{L}$ ranged from 3.23-13.17 $\mathrm{mmol} / \mathrm{L}$. According to Martínez-Porchas et al. (2009); Hastuti et al. (2003); Svoboda et al. (2001) increased glucose level caused by increase in glucocorticoids from the release of corticosteroids and catecholamines to overcome high energy requirements during stress.

In the first experiment, cholesterol level of estradiol-17 $\beta$ and $17 \alpha$-methyltestosterone treatment on day 30 and 60 showed no significant difference, however on day 0 cholesterol level was higher than day 30 and 60 . In the second experiment, cholesterol level of hCG and 
Ovaprim treatment on day 0,30 and 60 showed no significant difference. Cholesterol level on day 30 decreased then on day 60 increased again. According to El-Shafei (2017) cholesterol level on 7 days culture $(54.06 \pm 4.50 \mathrm{mg} / \mathrm{dL}), 14$ days $(55.06 \pm 6.40 \mathrm{mg} / \mathrm{dL})$ and 21 days $(56.06 \pm 3.52$ $\mathrm{mg} / \mathrm{dL}$ ) while according to Rakovac et al. (2008) mean $2.66 \mathrm{mmol} / \mathrm{L}$ ranged from $1.23-4.22$ $\mathrm{mmol} / \mathrm{L}$. Cholesterol is a major component of forming steroid hormones, such as progesterone, testosterone and estradiol, which act as the main components of the basic constituent of cell membranes and serve to maintain the permeability of cell membranes and energy reserves for reproductive activity. Cholesterol acts as a precursor to synthesis of steroid hormones in ovarian follicles. Steroid hormones play a role in vitellogenesis and maturation. The addition of the size of the egg diameter caused decrease in cholesterol level at vitellogenesis, but during the maturation process cholesterol level increased, this fluctuation occur because of use cholesterol in steroidogenesis (Reading \& Sullivan, 2017). According to Kocaman et al. (2005) cholesterol level in Oncorhynchus mykiss fish during reproductive period decrease in pre-maturation stage to maturation stage. This showed that there is use of energy reserves for reproductive activities. In the first experiment, testosterone hormone level of estradiol-17 $\beta$ and $17 \alpha$-methyltestosterone treatment on day 0,30 and 60 showed no significant difference. In the second experiment, testosterone hormone level of hCG and Ovaprim treatment on day 60 showed no significant difference. However, on day 0 testosterone hormone level in Ovaprim treatment was higher than hCG treatment and control, then on day 30 decreased and on day 60 increased again. According to Hefny et al. (2016) testosterone hormone level was ranged from $29750 \pm 4922 \mathrm{pg} /$ $\mathrm{ml}$ to $2690 \pm 2807 \mathrm{pg} / \mathrm{ml}$ with the lowest 17400 $\pm 1054 \mathrm{pg} / \mathrm{ml}$ and the highest $30500 \pm 2037 \mathrm{pg} /$ $\mathrm{ml}$. According to Kumar et al. (2015) $938 \pm 7.87$ $\mathrm{pg} / \mathrm{ml}$ while according to Yelghi et al. (2012) $11 \mathrm{pg} / \mathrm{ml}, 70 \mathrm{pg} / \mathrm{ml}$ and $370 \mathrm{pg} / \mathrm{ml}$. According to Reading and Sullivan (2017) increased testosterone hormone level can be affected by FSH which acts on the theca cell layer as the main regulator of estradiol production. The induction of treatment hormones is thought to stabilize the aromatization of testosterone to estradiol due to this process an increase in the level of estradiol in blood plasma and available in sufficient quantities can stimulate the liver to synthesize vitellogenin for oocyte growth to maximum size. In the first experiment, estradiol hormone level of estradiol$17 \beta$ and $17 \alpha$-methyltestosterone treatment on day 0,30 and 60 showed no significant difference. In the second experiment, estradiol hormone level of hCG and Ovaprim treatment on day 0,30 and 60 showed no significant difference, however on day 60 estradiol hormone level in control was higher than hCG and Ovaprim treatment. Estradiol hormone level in the treatment and control increased from day 0 to day 60 with the highest increased in control. According to Hefny et al. (2016) estradiol hormone level was $199 \pm$ $87 \mathrm{pg} / \mathrm{ml}$ and $102 \pm 16 \mathrm{pg} / \mathrm{ml}$, Kumar et al. (2015) $323 \pm 13 \mathrm{pg} / \mathrm{ml}$, Chang et al. (1995) $547.3 \pm 19.3$ $\mathrm{pg} / \mathrm{ml}, 533.1 \pm 54.1 \mathrm{pg} / \mathrm{ml}$ and $1354.1 \pm 297.0$ $\mathrm{pg} / \mathrm{ml}$ and Yelghi et al. (2012) 1800-3600 pg/ $\mathrm{ml}$. Increased estradiol hormone level result in stimulation of vitellogenesis which accelerates gonad development (Zahri et al. 2018; Sinjai et al., 2014).

\section{CONCLUSION}

The results showed that estradiol-17 $\beta$ and $17 \alpha$-methyltestosterone induction in mullet in size 9-14.7 $\mathrm{cm}$ increased gonad maturity to stage II while hCG induction in mullet in size 10-31 $\mathrm{cm}$ increased gonad maturity to stage III.

\section{ACKNOWLEDGMENT}

The author expresses gratitude to the UPTD PAPLWU Sungai Buntu Karawang West Java for the location to research. This research was funded by the Ministry of Research, Technology, and Higher Education of Indonesia with project no. 5648/IT3.11/PN/2017.

\section{REFERENCES}

Abdalhafid YKA, El-Mor M. 2014. Some aspects of the reproductive biology of the thin lip grey mullet Liza ramada (Risso, 1826) in Ain ElGhazala Lagoon-Eastern Libya. International of Journal Bioassays 3: 2041-2044.

Abdallah C, Ghorbel M, Jarboui O. 2013. Reproductive biology of the golden grey mullet Lizaaurata (Risso, 1810), in The Gulf of Gabes (Central Mediterranean, Tunisia). Mediterranean Marine Science 14: 409-415.

Acharjee A, Chaube R, Joy KP. 2017. Ovaprim, a commercial spawning inducer, stimulates gonadotropin subunit gene transcriptional 
activity: A study correlated with plasma steroid profile, ovulation and fertilization in the catfish Heteropneustes fossilis. General and Comparative Endocrinology 251: 66-73.

Achionye-Nzeh CG, Obaroh I. 2012. Ovaprim doses effects on eggs of African mudfish Clarias gariepinus. International Journal of Life Science and Pharma Research 2: 6-9.

Adebiyi FA, Siraj SS, Harmin SA, Christianus A. 2013. Induced spawning of a river catfish Hemibagrus nemurus (Valenciennes, 1840). Pertanika Journal of Tropical Agricultural Sciences 36: 71-78.

Aghuzbeni SHH, Hajirezaee S, Khara H. 2015. Polyculture of western white shrimp, Litopenaeus vannamei (Boone, 1931) with grey mullet, Mugil cephalus (Linnaeus, 1758) controls external parasites of Western white shrimp. Aquaculture Research 1-6.

Aghuzbeni SHH, Hajirezaee S, Matinfar A, Khara H, Ghobadi M. 2016. A preliminary study on polyculture of western white shrimp Litopenaeus vannamei with mullet Mugil cephalus : an assessment of water quality, growth parameters, feed intake efficiency and survival. Journal of Applied Animal Research $1-5$.

Albieri RJ, Araújo FG. 2010. Reproductive biology of the mullet Mugil liza (Teleostei: Mugilidae) in a tropical Brazilian bay. Zoologia 27: 331-340.

Ali MA, Rasheed SB, Hassan Z, Ibrar M, Majeed A, Ulhaq Z, Jan H, Jan Y, Hasanat A, Qureshi MS, Khan H. 2015. Efficacy of synthetic hormones ovatide and ovaprim in induced breeding of major Indian and Chinese carps. Journal of Agricultural Technology 11: 14491456.

Anil SK, Gunalan B, Jetani KL, Trivedi GK, Soundarapandian P. 2010. Determine the economic feasibility of the polyculture system (giant tiger shrimp and mullet). African Journal of Basic and Applied Sciences 2: 124-127.

Aziz EA, Kaleseran O. 2017. The influence of Ovaprim, aromatase inhibitors, and hypophysis on quality of catfish egg Clarias gariepinus. Budidaya Perairan Januari 5: 12-20.

Bartoňková J, Hyršl P, Vojtek L. 2016. Glucose determination in fish plasma by two different moderate methods. Acta Veterinární Brno 85: 349-353.

Chakrabarti P, Chatterjee N. 2014. Seasonal changes in the architecture of hepatocytes in relation to ovarian activities during growth, maturation, spawning and post-spawning phases in Mystus vittatus (Bloch, 1790). Journal of Entomology and Zoology Studies 2: 212-217.

Chang CG, Tan SC, Pan BN. 1995. Feed administration of estradiol-17 $\beta$ stimulates female differentiation in juvenile grey mullet M. cephalus. Zoological Studies 34: 257-264.

[CMFRI] Central Marine Fisheries Research Institute. 2014. Culture of grey mullet Mugil cephalus in backwater cage. Kerala (IN). hlm $1-2$.

El-Boray KF, EL-Halfawy MM, Mahmoud WF, Amin AM, Ramadan AM, Soliman YA. 2012. Growth and gonadal maturation of keeled mullet, Liza carinata, (Valenciennes, 1836) Cultured at different salinities. Journal of Aquatic Biology and Fisheries 16: 107-119.

El-Halfawy MM, Ramadan AM, Mahmoud WF. 2007. Reproductive biology and histological studies ofthe grey mullet, Liza ramada, (Risso, 1826) in lake Timsah, Suez canal. Egyptian Journal of Aquatic Research 33: 434-454.

El-Shafei HM. 2017. Alterations in the leucocytes and serum biochemistry in grey mullet (Mugil cephalus L.) fingerlings exposed to sub lethal doses of lead for different exposure periods. Journal of Aquaculture Research and Development 8: 1-5.

[FAO] Food and Agriculture Organization. 1999. The Living Marine Resources of The Western Central Pacific. Volume ke-4. Carpenter KE, Niem VH, editor. Rome (IT). hlm 2069-2108.

Ghanemi M, Khodadadi M. 2017. Effects of ovaprim administration on reproductive parameters of shirbot, Barbus grypus, Cyprinidae. Turkish Journal of Fisheries and Aquatic Sciences 17: 1025-1030.

Ghaninejad D, Abdolmalaki S, Kuliyev ZM. 2010. Reproductive biology of the golden grey mullet, Liza aurata in the Iranian coastal waters of the Caspian sea. Iranian Journal of Fisheries and Science 9: 402-411.

Hashemi SR, Kashi M, Safikhani H. 2012. Study at the reproductive cycle, gsi and maturation of Liza klunzingeri in Khuzestan coastal waters. Journal of Novel Applied Sciences 2: 35-39.

Hastuti S, SupriyonoE, Mokoginta I, Subandiyono. 2003. Blood glucose response of giant gouramy (Osphronemus gouramy, Lac.) to the stress of environmental temperature changes. Jurnal Akuakultur Indonesia 2: 73-77.

Hefny ASED, Abass OA, El-Halfawy MM, 
El-Regal MMA, Ramadan AM. 2016. Reproductive biology of keeled fish Liza carinata (Valenciennes, 1836) from Suez Bay, Egypt. International Journal of Aquaculture 6: $1-14$.

Isriansyah. 2011. Effectiveness of chronically administered HCG and $17 \alpha$-methyltestosterone hormone to $17 \beta$-estradiol concentration and egg development on green catfish Mystus nemurus. Jurnal Riset Akuakultur 6: 263-269.

Jhajharia A. 2011. Application of induced breeding practices for conservation of fishes in the Thar desert. Asian Journal of Environmental Science 6: 42-45.

Kocaman EM, Yanik T, Erdoğan O, Çiltaş AK. 2005. Alteration in Cholesterol, glucose and triglyceride levels in reproduction of rainbow trout Oncorhynchus mykiss. Journal of Animal and Veterinary Advances 4: 801-804.

Kumar P, Arasu ART, Kailasam M, Sukumarran K, Subburj R, Tyagraj G, Natarajan M. 2015. Gonadal development and steroid hormone profile of wild caught grey mullet Mugil cephalus. Biological Rhythm Research 46: 601-610.

Marimuthu K, Satthiyasilan N, Rahman MA, Arshad A, Raj MG, Arockiaraj J. 2015. Induced ovulation and spawning of African catfish Clarias gariepinus (Bloch) using ovaprim. Journal of Environment and Biotechnology Research 1: 2-9.

Martínez-Porchas M, Martínez-Córdova LR, Ramos-Enriquez R. 2009. Cortisol and glucose: reliable indicators of fish stress. PanAmerican Journal of Aquatic Science 4:158178.

Maryam H, Amin TM, Ehsan K, Mehdi GS, Arezoo V. 2011. Female reproductive biology of the klunzinger's mullet (Lizaklunzingeri) in the Persian gulf and the Oman sea. Journal of The Persian Gulf 2: 21-28.

Meseda, El-Gharabawy M, Assem SS. 2006. Spawning induction in the Mediterranean grey mullet Mugil cephalus and larval developmental stages. African Journal of Biotechnology 5: 1836-1845.

Mokhtar MA, Farah OM, Ali SM. 2015. Reproductive biology of Valamugilseheli from Sudanese Red sea coast. International Journal of Modern Plant \& Animal Sciences 3: 1-15.

Mousa MA. 2010. Induced spawning and embryonic development of Liza ramada reared in freshwater ponds. Animal Reproduction Science 119: 115-122.

Mousavi SE, Yousefian M. 2012. Effects of exogenous hormones on plasma cortisol, sex steroid hormone and glucose levels in male and female grass carp, Ctenopharyngodon idellus, during the spawning induction. African Journal of Biotechnology 11: 89208927.

Muchlisin ZA, Arfandi G, Adlim M, Fadli N, Sugianto S. 2014. Induced spawning of seurukan fish, Osteochilus vittatus (Pisces: Cyprinidae) using ovaprim, oxytocin and chicken pituitary gland extracts. AACL Bioflux 7: 412-418.

Mujtahidah T, Widodo MS, Faqih AR. 2016. $17 \beta$-estradiol level of nile tilapia Oreochromis niloticus after induced with supernatant of yellowfin tuna Thunnus albacares gonadal female. International Journal of ChemTech Research 9: 254-258.

Nahdi AA, Marzouqi AA, Shajibi SA, Hosni AA. 2008. Length-weight relationships, maturity, and reproductive season of the fringelip mullet Crenimugil crenilabis (Forsskål, 1775) from the Arabian sea coast of Oman. Journal of Agricultural and Marine Sciences 13: 23-32.

Nuraini, Alawi H, Asiah N, Priyatama AT. 2012. Induced spawning of selais fish Ompok hypopthalmus under different doses of human chorionic gonadotropin hormone (HCG). Jurnal Perikanan dan Kelautan 17: 1-10.

Okere E, Erondu ES, Zabbey N. 2015. Evaluating the efficacy of pituitary gland extracts and Ovaprim in induced breeding and fry quality of Clarias gariepinus, burchell (pisces: claridae). Agriculture, Forestry and Fisheries 4: 71-76.

Pinto AL, Varandas S, Coimbra AM. Carrola J, Fontaínhas-Fernandes A. 2010. Mullet and gudgeon liver histopathology and macroinvertebrate indexes and metrics upstream and downstream from a wastewater treatment plant (Febros River-Portugal). Environ Monit Assess 169: 569-585.

Putra WKA, Razai TS. 2017. Effect of pure and combine hormone of pregnant mare serum (PMSG) on gonadosmatic index, hepatosomatic index of silver pompano fish Trachinotus blochii. Journal of Aquaculture Science 2: 61-71.

Rachimi, Raharjo EI, Sudarsono A. 2015. Effect of concentration HCG hormone and Ovaprim 
againts hatcing rate and survival rate of kelabau Osteochilus melanopleura (Blkr.). Jurnal Ruaya 5: 11-17.

Rajeshkumar. 2015. An integrated use of histological and ultra-structural biomarkers in Mugilcephalus for assessing heavy metal pollution in east berbice-corentyne, Guyana. International of Journal Bioassays 4: 45414554.

Rakovac RC, Perovic IS, Popovic NT, Hacmanjek M, Smuc T, Jadan M, Lipej Z, Homenk Z. 2008. Cage culture effects on mullets (mugilidae) liver histology and blood chemistry profile. Journal of Fish Biology 72: 2557-2569.

Rawat A, Chaube R, Joy KP. 2017. Effects of the fish spawning inducer ovaprim on vasotocin receptor gene expression in brain and ovary of the catfish Heteropneustes fossilis with a note on differential transcript expression in ovarian follicles. General and Comparative Endocrinology 241: 24-32.

Reading BC, Sullivan VC. 2017. Vitellogenesis in Fishes. North Carolina (US): Elsevier Inc. hlm 1-12.

Rehman MH, Ashraf M, Abbas F, Qureshi IA, Hassan MM, Iqbal KJ, Abbas S. 2015. Effect of different doses of ovaprim (sgnrha+domperidone) on the egg fecundity and reproductive hormone levels in Channa marulius. The Journal of Animal \& Plant Sciences 25: 1585-1590.

Rostami SAMH, Amini K, Khani F, Miandare HK. 2016. Grey mullet Mugil cephalus rearing normative as a new species in Gomishan, Golestan Province. Environmental Resources Research 4: 46-55.

Saoudi H, Aoun L. 2014. Pages grey mullet (Mugil cephalus L.) reproduction cycle in the northeast of Algeria, Mediterranean sea. Journal of Applied Science and Agriculture 9: 66-76.

Shehadeh ZH, Madden WD, Dohl TP. 1973. The effect of exogenous hormone treatment on spermiation and vitellogenesis in the grey mullet, Mugil cephalus L. Journal of Fish Biology 5: 479-487.

Sinjai H, Ibo F, Pangkey H. 2014. Evaluasi kombinasi pakan dan estradiol-17 $\beta$ terhadap pematangan gonad dan kualitas telur ikan lele dumbo Clarias gariepinus. Jurnal LPPM Bidang Sains dan Teknologi 1: 98-112.
Sukendi, Thamrin, Putra RM. 2016. The improvement of ovulation stimulation and egg quality of pawas fish (Osteochillus hasselti $\mathrm{CV)}$ for artificial spawning requirements in seed production. International Journal of Applied Environmental Sciences 11: 11731181.

Sulistiono, Jannah MR, Ernawati Y. 2001. Reproduction of mullet Mugil dussumieri in Ujung Pangkah Water, East Java. Jurnal Iktiologi Indonesia 1: 31-37.

Suriansyah, Sudrajat AO, Zairin Jr M. 2011. Study on gonad development of climbing perch (Anabas testusdineusBloch) with Hormonal Stimulation. Berita Biologi 10: 511-520.

Svoboda M, Kouril J, Hámácková J, Kaláb P, Savina L, Svobodova Z, Vykusová B. 2001. Biochemical profile of blood plasma of tench (Tinca tinca L.) during pre and post spawning period. Acta Veterinaria Brno 70: 259-268.

Tayel SI, Ahmed NAM, EL-Hossiny MA. 2014. Impact of diffused pollution on histological and hematological properties of Mugil cephalus and Mugil capito collected from lake Manzalah, Egypt. International Journal of Environmental Science and Engineering 5: 51-67.

Vazirzadeh A, Ezhdehakoshpour A. 2014. The effects of different hormonal treatments on the oocyte maturation in wild grey mullet Mugil cephalus collected from the Iranian coastal waters of the Oman sea. Iranian Journal of Ichthyology 1: 17-22.

Wigati KN, Syafei LS. 2013. Reproduction and spawning patterns of the mullet (Moolgarda engeli, Bleeker 1858) in Mayangan coastal waters, West Java. Jurnal Iktiologi Indonesia 13: 125-135.

Yelghi S, Shirangi SA, Ghorbani R, Rostami KHA. 2012. Annual cycle of ovarian development and sex hormones of grey mullet (Mugil cephalus) in captivity. Iranian Journal of Fisheries Sciences 11: 693-703.

Yilmaz D, Kalay M, Donmez E, Yilmaz N. 2016. Assessment of biological effects of environmental pollution in Mersin Bay (Turkey, Northeastern Mediterranean Sea) using Mullus barbatus and Liza ramada as target organisms. Environmental Pollution 208: 361-370.

Yones AMM, Metwalli AA, Al-Jilany SSA. 2016. 
Effect of artificial diets on growth performance, body composition and gonad maturation of mullet (Liza ramada). International Journal of Fisheries and Aquaculture Research 2: 28-49. Yousefian M, Ghanei M, Pourgolam, R, Rostami, HKH. 2009. Gonad development and hormonal induction in artificial propagation of grey mullet, Mugil cephalus L. Research Journal of Fisheries and Hydrobiology 4: 35-40.

Zahri A, Sudrajat AO, Zairin Jr M. 2018. Profil hormon FSH, LH dan estradiol serta kadar glukosa darah sidat, Anguilla bicolor bicolor (Mc Clelland, 1844) yang dirangsang hormon HCG, MT, E2 dan anti dopamin. Jurnal Iktiologi Indonesia 18: 57-67.

Zeinab A, El-Greisy, Shaheen AA. 2007. Comparative difference between the effects of LHRH-a, $17 \alpha$-methyltestosterone pellets and HCG on reproductive performance of Mugil cephalus. Journal of Applied Sciences Research 3: 890-895. 